\title{
Crucial Legislative Reforms in Public Administration in Slovakia Since 1990
}

\author{
By Irina DudinskÁ* and Michal Cirner**
}

\begin{abstract}
Public administration in Slovakia since 1990 has under constant change and is related to the ongoing transitions and unstable political environment after the fall of the former regime. Political, professional intervention and interference, an absence of long-term vision in public administration, has resulted in chaos and despite the advice of experts created a constant cycle of problems from which other transforming countries should learn from. After more than 25 years of transformation Slovakia can boast about partial successes even in public administration. It has not only become a memento of mistakes but also an example of successful implementations of reforms, particularly in the area of decentralization of public administration.
\end{abstract}

Keywords: Public administration, reform, legislative changes, Slovak Republic, decentralization

\section{INTRODUCTION}

The events in 1989 represented a watershed in the development of the public administration in the Central European area. After the political regimes switched to liberal democratic, each segment of the society including the public administration, started transformation processes that, 25 years later, have not yet been completed and some already require revision. The political and historical background combined with the efforts to catch up with Euro-Atlantic trends moved Slovakia from a learning position, where it was being inspired by reforms carried out in other countries towards a position where it might experiment and implement significant changes in public administration within a relatively short period of time. Slovakia switched from an observation position, accepting various public administration models to being the country whose experience with the public administration reform is applicable in the countries facing such reforms. "No reform should be sold as a marketing product that we look at with mistrust. The best appreciation of changes is when citizens will get used to them and start to speak highly of them". "Universal revocation of privileges, salary freezing, trimming apparatus budgets is not a pleasant or wished matter. Politicians do not do it often because of their reform agility or savings introduce similar steps, but it is because of considerable public pressure, in pre-election period or during a crisis, when politicians have to demonstrate that they are able to "tight their belts" ... it will likely be a pragmatic process in stages of agreement between citizens and politicians to the intent that what you allow us to keep we will keep and what will worry you very much we will change". ${ }^{2}$

* Associate professor and head of Institute of Political Science, Faculty of Arts, University of Prešov. E-mail: irina.dudinska@unipo.sk

** Assistant professor and secretary of Institute of Political Science, Faculty of Arts, University of Prešov. E-mail: michal.cirner@unipo.sk

1 Cirner (2013) 69.

2 Cirner, Polačková (2012) 147. 


\section{UNDERSTANDING PUBLIC ADMINISTRATION REFORM}

The reform of public administration represents a certain specific type of a reform which is connected with state administration and self-government. According to the short dictionary of the Slovak language, a reform is "change, modification in order to improve something". 3 The Open Encyclopaedia of Philosophy understands reform as "rebuilding of something, modification, change, transformation of conditions through gradual improvements and adjustments". According to Kolarská-Bobinská ${ }^{5}$ reform is "intentional implementation of changes". Beblavý $y^{6}$ understands reform as "a specific set of public policy measures aiming at a significant and rapid public policy change in a certain area to achieve a qualitatively new state". Generally, in the case of public administration reform it related to a complete change of philosophy. Reform concerns changes in activities, organization and status of public administration employees. The changes do not have to apply to the entire public administration system but only to some of its components. ${ }^{7}$ Public administration reform mostly represents a set of interactive changes that are part of the reform process e.g., inspection mechanism reform, public finance reform. ${ }^{8}$

There may be different reasons for undertaking public administration reform. According to Drechsler, the major reasons for undertaking changes include fashion, ideology, corruption and problem-solving. He states "With fashion I mean, you reform the public administration in a certain way because everybody does it [...]. Everybody's doing it, so you do it too because that is, of course, peer pressure, that is what makes you active. Second, ideology. What is an ideology? A reduced worldview because you can't cope with the complexities of the world. You believe that the state is good, the state is bad, something like that. And then you commit a certain reform based on that ${ }^{\text {" }} .9$ This author also points out that problem-solving is an extremely rare reason for reforms.

Light (2010) states that public administration reorganization is sparked by six factors: (1) growth in population size, area, or clientele served by an agency; (2) a change in the functions undertaken as a result of new problems faced by an agency; (3) a change in the philosophy of a government program; (4) the consequences of new technology, new equipment, and advancing knowledge; (5) the rising qualifications of personnel; (6) actions taken above agencies that frequently force changes upon them. In this respect, he also points out that "reorganizations are efforts to adapt their organizations to their surrounding environments, an effort to overcome organizational obsolescence and an attempt to return organizations to "normal equilibrium." Reorganizations periodic reoccur as a part of organizational growth, change, or decline and thus can be considered as a normal and necessary activity". ${ }^{10}$

The scope, focus and time frame of public administration reforms are also diverse. In general, they are set in the public administration reform strategy ${ }^{11}$ and the focus of reforms

\footnotetext{
3 Kačala, Písarčíková, Považaj (2003).

4 Piaček, Kravčík (1999).

5 Kolarská-Bobinská (2000) 7.

6 Beblavý (2002) 57.

7 Hendrych (2011).

8 Belajová, Balážová (2004).

9 Drechsler (2011) 17.

10 Light (2010) 372-373.

11 Hendrych (2011).
} 
may point "to cost-cutting in public administration or some of its components, to improving the structure of decision-making through centralization or, vice versa, decentralization or deconcentration of decision-making powers, to strengthening the public service function as a fundamental expression of modern democratic public administration". ${ }^{12}$ The efforts of many countries to make public administration more flexible, simpler and cheaper but also more democratic by increased participation of citizens in managing public affairs has, in the past 25 years, led to the creation of a theoretical base specializing in the reform and modernization of public administration labelled as a theory of reforms. ${ }^{13}$

\section{CENTRALIZE OR DECENTRALIZE? THE TOLERANCE OF LOCAL PECULIARITIES AND COMMON SENSE}

The key theoretical and practical problem in efficient public sector decision-making is the determination of the proportion between centralized and decentralized decision-making, where an important criterion is the efficiency of public goods and service allocation. As every country has different specific conditions, it is not possible to determine a unified prototype of the optimum relation between centralization and decentralization. Universally, any specific function should be fulfilled by the level of public administration that can manage most efficient and effective consideration of spatial dimension of different types of public goods. ${ }^{14}$

The relations between the state administration and self-government and their position in the public administration structure may be equal or unequal and it depends on the type (model) of the state. "The centralist model gives less space to self-government because especially the position of self-government is weak, which has an effect on the scope and contents of competences. It is a model in which the position of self-government is unequal; the state administration dominates". ${ }^{15}$ The weakness of centralized states is not only the geographic distance between the government seat and individual regions, which causes a deficit in understanding local issues, but also psychological differences between the government officials and citizens. ${ }^{16}$

On the other hand, the decentralist state model assumes a more equal position of the bodies of the state administration and self-government. "Political decentralization (devolution) [...] presupposes the transfer of attributions and afferent decisional powers to the local level of government and the implicit limitation of the central intervention capacity". ${ }^{17}$ Decentralization as a process is usually associated with the transfer of competences from the state administration to self-government but can also mean the transfer of powers to the third sector.

It is necessary to highlight that, in the countries where decentralization process was carried out in different forms, "the still existing central government (the centre) has the ultimate power with respect to the units; the decentralization or recentralization process is in power of the centre". ${ }^{18}$ It must also be pointed out that not all functions of public

12 Hendrych (2011) 387.

13 Pomahač, Vidláková (2002).

14 Žárska, Černěnko, Kozovský (2010).

15 Žárska, Černěnko, Kozovský (2010) 12.

16 Cabada (2007).

17 Matei, Popa (2010) 260.

18 Vykoupilová (2007) 17. 
administration may be centralized. Decentralizing national government will still keep certain concept and control functions. Decentralization has strengths and understandably, has weaknesses which offers an argument for pushing centralization forward. "Important impulses towards spreading the multi-level governance model were brought by political studies from the second half of the 1950s which claimed that competition among (many) self-government bodies led to improved performance and efficiency of public administration as well as the studies from the 1990s claiming that multi-level governance enables decision makers to reflect the heterogeneity (of society)". ${ }^{19}$

\section{THEORIES INTERFERING WITH REFORM PROCESSES IN THE PUBLIC ADMINISTRATION IN SLOVAKIA}

The changes in the public administration that were produced in western countries and outside the socialist block from 1960s entered the central European area theoretically and practically. The initial changes emerged in the United States and Western Europe and focused on the elimination of bureaucracy in the institutional system of governance and administration. In the 1970s, the introduction of new technologies in different fields, including the public sphere, was commonplace. ${ }^{20}$ The concept of public management emerged at the turn of 1970s and required the application of "innovative management elements" in public administration. ${ }^{21}$ The concepts of decentralization, deregulation and privatization did not emerge until the 1980s because "the 1980s were a decade of many urgent challenges. Government and administrative authorities [...] were concerned about [...] circumstances, such as economic and financial pressure built up by fiscal resistance, changing nature of industrial and financial markets, quickly-changing political environment, the need to initiate dramatic changes in administrative policy, growing ideological bias against the administrative state, technological and management revolution along with doubts about the efficiency of procedures and techniques that the government and administration activities leaned on in the long term". ${ }^{22}$

In connection with the aforementioned challenged "in the mid-1980s more authors drew attention to insufficient results achieved by the introduction of public management ideas into practice. The outcome of such efforts was the development of an ideological movement called new public management, and it sought to look at administration and governance as an activity that is comparable to entrepreneurship. The most important element of the ideological movement was justification of inevitability to shift from policy to management and from centralized planning and management to the decentralized system of relatively autonomous public agencies". ${ }^{23}$ "There has been ... a shift ... towards emphasizing the priority to be business-like, pushing the state out, supporting management and entrepreneurship, creating new structures free of bureaucratic interventions, introducing performance-related pay and contracting out of services to the private sector according to competitive tendering and privatizing. These and other similar practices were labeled as the term "new public management". ${ }^{24}$

19 Vykoupilová (2007) 17.

20 Pomahač (2011).

${ }^{21}$ Klimovský (2008).

22 Pomahač (2011) 232.

23 Klimovský (2008).

24 Chapman (2003) 250. 
New public management is a system of management methods derived from market economy. Its main aim is to save money as well as improve benefits i.e., a shift from spending to cost cutting. The theory of new public management combines public choice theory, rooted in the economist's theory of rational behaviour and Neo-Taylorism, based on management theory. ${ }^{25}$ The public sphere is currently dominated by pair of theories. The management movement or economic-management movement draws from public management theories, new public management and lean administration. The other is known as the political movement which leans on the concept of public policy creation and good governance. These approaches overlap and are mutually complementary. ${ }^{26}$

Hamalová $^{27}$ claims that moderate manager-ism is rather characteristic of most transitional countries, which can include Slovakia. This moderate manager-ism focuses on merging private and public management as well as applying management methods in governance as well as the decentralization of public administration and the public sector reform. It can be said that reform processes carried out in public administration in Europe in the 1990s were based on changes in the four fundamental areas: fiscal regulation and adaptation, effectiveness, increasing competences, transparency and responsibility. ${ }^{28}$

"The application of the new public management concept ... towards effective and professional public administration, while intensely drawing inspiration from the private sector is also a part of the aforementioned reform procedures. New public management is based on several basic postulates: elimination of hierarchic organization, decentralization of decision-making, decentralization of responsibilities, contract approach management, participatory management, introduction of entrepreneurial controlling and accounting“" ${ }^{29}$

After 1989, such theoretical constructs became the base for the reforms of the public administration in the Slovak Republic (SR). Reforms carried out after 1998 due inspiration from the Benelux and Scandinavian countries. However, the political situation, and political willingness or unwillingness that arose in Slovak public sphere had a major influence on the course and result of partial changes in the public apparatus. The social aspect and appeal should play an important role in changing the country in which the public requires system changes and wants to participate. However, after the fall of the totalitarian regime, society at a whole as well as the socio-political and economic systems was at a crossroads.

\section{SOCIETY, POLICY, ECONOMY AND TRANSFORMATION PROCESSES OF PUBLIC ADMINISTRATION IN THE SLOVAK REPUBLIC}

The character of the environment in which public administration reforms are implemented is extraordinarily important to achieve success. The conditions and environment of the Slovak Republic was not ideal but rather unstable, in terms of economy, society and policy and this resulted in a significant polarisation of society. ${ }^{30}$ The story of the Slovak reforms lies behind a complicated political situation. Between 1991 and 1992, the future organization of the Czechoslovak Federative Republic was being discussed and resulted with a split and the establishment of two new states. Between 1992 and 1994, there was a serious dispute

\footnotetext{
25 Hamalová (2007).

26 Klimovský (2008).

27 Hamalová (2007).

28 Ručinská, Knežová (2009).

29 Ručinská, Knežová (2009) 174.

30 Nižňanský (2002).
} 
over establishment of democracy that resulted in the fall of the government and early elections. The years between 1994 and 1998 resulted in the international isolation of Slovakia and incredible stealing of common assets. ${ }^{31}$

The third government of Vladimir Mečiar (1994-1998) was characterized as a period of unconsolidated democracy. The regime, shaped after the 1994 elections, was fairly untypical of the development of democracy in Central European countries. The only equivalent authoritative ruling could only be found in the ruling form of the Croatian president Fran̆o Tudjman. Both types of ruling are labeled as hybrid regimes in political literature. ${ }^{32}$ The period of Mečiar's ruling, especially his third office term when he was prime minister, caused that the transformation of public administration in Slovakia. It was influenced by a significant opinion disunity of political elites on fundamental issues of the whole political system, as a unit, as well as public administration. ${ }^{33}$

A bad social and economic situation played a negative role in the transformation process. The quality of life in Slovakia was at the tail end of Europe; unemployment was growing in huge numbers; and there was a threat of cross-default i.e. inability of state to fulfill its financial obligations. Such conditions did not feed any principal changes because society finds it easier to cope with any inconvenience related to changes in the times of prosperity. ${ }^{34}$

After the 1998 elections, the main objective was to guide Slovakia out of isolation which was eventually achieved by the accession of the Slovak Republic to the European Union, NATO and OECD. There was gradual consolidation of public finance through the "belt-tightening" austerity measure packages. The first short period of consensus between the leading powers (government and non-governmental sector) was between 2002-2004, when political and economic reforms were implemented. The economy started to thrive, GDP growth and further economic indicators made rating agencies and media compare Slovakia to an economic tiger of the Central Europe.

Growing disagreements in the ruling coalition slowed down the process of positive changes. This completely stopped after 2006, despite the accession of Slovakia to the Eurozone, with adoption of the euro as national currency, and the Schengen Area. The performance of the economy and subsequent boom was slowed down by the economic and financial crisis that has not eased since 2008. A change of government in 2010 raised hope for reforms in the form of centrist right-wing government coalition, but the internal incoherence and disunity led to early elections. The left-wing SMER-SD party won a landslide victory in the 2012 parliamentary elections, legally and legitimately forming a single-party government. Their intention to focus on a strong and social state was apparent from their previous government activities (2006-2010).

The government was stable and remained in power until the 2016 elections. They are struggling with the problems of the economic crisis and growing unemployment, which also affects the EU and Eurozone. The government seeks to solve the problems by government measures, such as tax and fee increases, stimuli for entrepreneurs, public expenditure cuts and saving. There are different political and expert opinions on such measures but the ESO (effective, reliable and open state administration) reform, aiming at public administration reforms, and saving public finance is becoming a reality.

31 Nižňanský (2010).

32 Hloušek, Kopeček (2003).

33 Nižňanský (2005).

34 Nižňanský (2010). 
All public administration reforms since 1990, whether completed, ongoing or stagnating, except the official concepts, proclamations and outcomes in the form of practical applications, also have their visible or latent political connotations. By emphasizing them we can better understand all aspects of the changes that had been discussed.

\section{CRUCIAL SYSTEM TRANSFORMATIONS OF PUBLIC ADMINISTRATION SINCE 1990 IN SLOVAKIA}

One of the initial and major changes after November 1989 was the closure of the national committees that until then managed the state administration and to a limited extent also self-government. "Constitutional Act of the Federal Assembly No. 294/1990 Coll. cancelled the relevant provisions on national committees and established self-government at the municipal level". ${ }^{35}$ This amendment later gave a rise to Act No. 369/1990 Coll. on municipal establishment which "provides municipalities with an opportunity to develop more thoroughly, in detail and legally precise powers as well as obligations laid down in it". ${ }^{36}$

At the local level, mayors and municipal councils are directly elected bodies. Municipalities are separate territorial and administrative units in the Slovak Republic. Mayors are representatives of a village, town of city and the supreme executive municipal body. The mayor's office is a public function. Mayors convene and chair municipal council meetings and policy advisory committees and sign their resolutions, execute municipal management, represent their municipalities in dealings with state authorities, businesses and persons, decide concerning all matters of municipal management that are not served to municipal councils under the current legislation or municipal statute. In addition, mayors are statutory bodies of their municipalities. They may suspend the execution of some municipal council resolutions if they believe that they contradict the legislation or are apparently disadvantageous for the municipality. Mayors also have a deputy. The deputy mayor is nominated and dismissed by the mayor and municipal councils may establish or dismiss, if necessary, permanent or temporary executive, audit or advisory bodies, especially, a policy advisory committee, panels and they define the scope of their work. Municipal councils decide concerning elementary questions in the municipal life that are mentioned above as the scope of their activities. ${ }^{37}$ Municipal offices are responsible for organizational and administrative matters of the municipal council and mayors as well as bodies established by the municipal council. If the municipality has a position of the head of the office, they manage the office and organize its work, otherwise it is the mayor responsibility. The head of the office is nominated and dismissed by the mayor. The chief auditor is elected and dismissed by the municipal council. Municipality may establish their own municipal police. Municipalities may mutually cooperate according to agreements and may form associations of municipalities. Within the scope of their activities, they may also cooperate with other territorial and administrative authorities or authorities of foreign countries that perform municipal functions. They are also entitled to become members of international associations of territorial units or authorities. ${ }^{38}$

Thus, municipalities gained political independence, legal status and a basic package of competences as well as responsibilities but they are economically dependant upon on the

35 Kováčová (2010) 65.

36 Sotolář (2003) 9.

37 (Act No. 369/1990 Coll.)

38 Cirner (2014). 
state. Act No. 427/1990 Coll. is about transfer of state ownership of certain entities to other legal or natural persons in amended version but Act No. 138/1991 Coll. Regarding municipalities property as amended played a significant role. Municipal ownership was acquired by applying a territorial principle i.e., title was assigned to the municipality in which property was located. ${ }^{39}$

Reorganization at the local state administration was also required in connection to organization of self-government. The Slovak National Council adopted Act No. 472/1990 Coll. for the organization of local state administration. Under this law, the competences of former national committees were divided between municipal offices, newly established district and circuit offices and some ministries. ${ }^{40}$

The territorial organization of state has been changing since 1 January 1991. "The regional level of state administration was abolished (former Western Slovak, Central Slovak and East Slovak Regions and Bratislava as a separate region)". ${ }^{41}$ The administrative organization was given by the existence of 38 district offices and 121 circuit offices. The local state administration was carried out by the state and different authorities of specialized state administration within the defined administrative units e.g. tax authorities, customs authorities, environment authorities, labour offices. ${ }^{42}$

In the period between 1990-1996, several proposals with the aim to continue changes were prepared. The Ministry of Interior proposed to divide Slovakia in 16 large districts. Between 1991 and 1992 three committees were set up to prepare a proposal of a new territorial and administrative division of Slovakia. The kotar county variant (župa) received best evaluation, 16 kotar counties (župas) and 77 districts. Despite being accepted by the ruling parties, it was not submitted to a hearing in the Slovak National Council and after the 1992 elections, a new committee was appointed. It submitted a proposal for principles of territorial and administrative division as well as a proposal for the concept of local public administration. In 1994, the Strategy for Local Public Administration Reform was prepared. Between 1995 and 1996, the Ministry of Interior prepared a bill on territorial and administrative organization of the Slovak Republic and the kotar county (župa) variant was rejected. ${ }^{43}$

Another important step towards the public administration reforms in Slovakia was taken in 1996 and involved territorial organization. The system of circuit offices was abolished and pursuant to Act No. 221/1996 Coll. on territorial and administrative organization of the Slovak Republic; Act of the National Council of the Slovak Republic No. 222/1996 Coll. on organization of local state administration, 79 district offices were established in the position of the basic level of territorial state administration, regional division was formed and eight regional offices in the position of the secondary level of state administration were formed. ${ }^{44}$ Apart from 79 district offices, there were also 41 permanent and temporary branches of district offices. Despite the efforts to achieve maximum integration, 23 networks of specialized offices of state administration remained.

39 Papcunová, Gecíkova (2011).

40 Pilát (2002).

41 Pilát (2002).

42 Búšik (2005).

43 Nižňanský (2010).

44 Hamalová, Papánková (2005). 
However, the new territorial and administrative divisions met with extensive criticism. Slovak experts like Viktor Nižňanský or Dušan Sloboda and many others agreed that the establishment of 79 districts created units too small to function effectively and to fulfill specific development programs. The establishment of 8 regions was especially criticized for disrupting the natural regional differentiation of Slovakia. Anomalies, such as the division of Spiš, a natural historical region, between Prešov and Košice regions. ${ }^{45}$

In addition, the organization of local state administration and rejection to strengthen self-government was motivated by efforts to strengthen the government of that time and "efforts to weaken the position of Hungarian ethnic minority. Not only domestic representatives of self-government, non-governmental organizations, some opposition politicians, but also European institutions protested against the solution and procedures". ${ }^{46}$

These allegations, according to Kling, ${ }^{47}$ were supported by when new districts were created where there was a significant disproportionality of population of individual districts, which was, in theory, supposed to maximize the number of votes for the largest ruling party (HZDS). "As a consequence of political struggle and an absence of a clear vision and future direction of the state, in public administration the self-government principles were inhibited in favor of a strong state administration [...] in that period political representatives only adopted the measures that $[\ldots]$ could have been used for maintaining narrow partisan interests $[\ldots]$ which would be instrumental in the process of gaining or holding power". ${ }^{48}$

After the 1998 parliamentary elections, more favourable conditions for continuation of the reform process were created. In their program statement, the new government assigned high priority to "solving optimum organization of public administration so that it provides basic needs for citizens. Situation requires that the decentralization of state competences to lower elements of public administration continue while respecting the principle of subsidiarity"49 (SR Government Office, 1998). After 1999, the preparation of required materials and legislative standards for fulfilling the aforementioned goals of the new government started.

In decree No. 695/1999 of August 1999, the government took into account the Public Administration Reform Strategy. The objectives of the strategy include principles of organizing public administration and also concepts that must be executed within the complex reform of public administration. With this document, the government adopted the separate model of public administration, i.e. the institutional segregation of the performance of state administration and performance of self-government and continuation in the process of decentralizing responsibility for provision of public services from state administration to self-government. Moreover, the government adopted the decentralization and modernization

45 For example, famous cultural and historical sight, Spiš Castle, belongs to the Košice SelfGoverning Region but the surrounding areas belong to the municipality of Spišské Podhradie which is a part of the Prešov Self-Governing Region.

46 Nižňanský (2010) 175.

47 Kling (2008).

48 Machyniak (2012) 126.

49 "In terms of the political and economic situation the government will solve optimum organization of public administration so that it provides basic needs for citizens. This requires that the decentralization of state competences to lower elements of public administration continue while respecting the principle of subsidiarity. The government will guide the process with respect to total performance of economy so that the decentralized responsibilities are relevantly covered by financial resources“ (SR Government Office, 1998). 
of public administration as a program of long-term character through the National Programme for the Decentralisation and Modernisation of the Public Administration in the SR.

Another document, that was the basis of the entire following reform process, was the Concept of Decentralization and Modernization of Public Administration. The government approved it in its decree No. 230 in April 2000 as a fundamental document and document for performing further work. The concept, as its title suggests, primarily deals with decentralization and modernization of public administration. In terms of decentralization, it particularly emphasizes the decentralization of competences and public finance and also the organization and control of public administration.

In terms of modernization, government mainly focuses on legal framework and management in public administration but also on education and informatization in public administration. ${ }^{50}$ The Concept of Decentralization and Modernisation of Public Administration develops principles that were defined in the reform strategy and respects general principles of civic society, subsidiarity, effectiveness, transparency and flexibility of public administration as well as obligations that are defined in the SR government's program statement.

As previously mentioned, the former government in $1996^{51}$ sought a territorial reform but their main effort was to organize Slovakia in order to maximum voter potential. Therefore, the effort "to divide the territory was subject to political criteria that were characterized especially by dividing several traditional regions, dividing districts with prevailing Hungarian population and numerous shifts of municipalities within neighboring regions". ${ }^{52}$ However, the territorial and administrative division may be considered effective when it reflects the existing territorial structure of society based on natural regions to the maximum extent.

The government's first measure within the issue, was to appointed Viktor Nižňanský as a governmental plenipotentiary for public administration reform and as a result he submitted several projects to the government. In his opinion, the new self-governing regions were supposed to be called kotar county (župa) and to respect the historical perspective and his proposal anticipated 12 kotar counties (župas). However, his vision was not accepted by the ruling political parties and no compromise was reached. The proposal for a change in territorial division from 8 to 12 higher territorial units (župas based on natural regions) was rejected by that-time ruling parties SDL' and SOP that joined the opposition, which almost led to the fall of the government.

Eventually, in 2001 the original model of 8 regions called higher territorial units won with members of parliament approved the establishment of self-governing regions and "small" Act on Competences that enabled the transfer of competences in 2002-2004 to municipalities and self-governing regions. In December 2001, the first elections for posts, including president of self-governing region, members of self-governing region parliament in self-governing regions took place. The election turnout had been relatively poor until now, around $20 \%$ of entitled voters. From the constitutional perspective, the most important change came with the amendment to the Constitution of the SR, in particular, chapter four about territorial self-government. The change concerned the position of the second level of

50 Nižňanský (2005).

51 In July 1996 Slovakia administratively divided in 8 regions and 79 districts.

52 Hambálek (2011). 
self-government, higher territorial units that had not been laid down in the Constitution of the SR.

In terms of regional governments, citizens elect the president of self-governing regions and members of regional councils in a direct election. Presidents convene and chair regional council meetings and are responsible for external representation. Presidents act as a statutory body in property, labor and other relations. They also decide in the matters that are conferred on self-governing regions under the current legislation. Regional councils set up mandate committees and financial committees and may establish other committees as permanent or temporary advisory, initiative and audit bodies. Regional councilors, as well as other person appointed by the regional council, serve on the committees. The council of the self-governing region may approve generally binding regulations. The administrative and organizational matters of the council, its president and other bodies formed by the council are handled by an office that comprises the staff of the self-governing region. The work of the office is managed and arranged by the head of the office, who reports to the president. The chief auditor, who is elected staff member of the self-governing region, monitors the performance of the tasks of the self-governing region, monitors revenue and expenditure of the self-governing region budget and monitors the management and handling of real estate property. The self-governing region funds itself from its own revenues as well as from state allocations. Within the scope of its activities the self-governing region may cooperate with other territorial or administrative authorities or authorities of foreign countries that perform regional functions. It is also entitled to become a member of international associations of territorial units or authorities..$^{53}$

"However, the reform of public administration is not only about the decision on territorial and administrative division and establishment of self-government of higher territorial units but must be a complex change in administration of public affairs. Other important steps also include the transfer of competences from the state to self-government, decentralization of financial flows and solution of ownership issues. For these reasons in September 2001, the National Council of the SR adopted Act No. 416/2001 Coll. on the transfer of certain competences from state administration bodies to municipalities and higher territorial units, as amended by Act No. 567/2001 Coll. - Competency Act". ${ }^{4}$

The competences listed in Act No. 416/2001 Coll. are according to the Constitution of the SR divided in original competences and transferred performance of state administration. Within the scope of original competences, municipalities act in their own name and within the scope of transferred performance of state administration in the name of state. Selfgovernments perform original competences in the above-mentioned areas but, according to their financial opportunities and own resources, they must reach a consensus of citizens and members of parliament or self-government authorities. ${ }^{55}$ The state does not intervene in performance of original competences. However, the state may influence the transferred competences and transfer them to self-government in cases if self-government can carry them out more efficiently and faster than the state. However, there is a rule that anywhere where self-government has assigned competences or the state intervenes, the state assigns powers and also financial resources.

53 Cirner (2014).

54 Neubauerová (2003) 64-65.

55 Králik (2007). 
Act No. 416/2001 Coll. on transfer of certain competences from state administration bodies to municipalities and higher territorial units, as amended, lays down the interpretation rule that if legislation regulating competences of a municipality or higher territorial unit does not regulate that is transferred performance of state administration, then it is performance of self-administrative competency of municipality or higher territorial unit. The determination of original and transferred competences also has serious consequences from the perspective of funding as well as perspective of performance and control. ${ }^{56}$

The second government of Mikuláś Dzurinda, formed after the 2002 elections, and they made commitments, in their programme statement, to continue the reforms and decentralization of public administration. In its first half-year, they adopted two principal documents, the project of decentralization of public administration for 2003-2006 and the concept for organization of local state administration. In 2004, tax reform was carried out in Slovakia as a condition for implementation of fiscal decentralization i.e., new way of funding municipalities and higher territorial units. It significantly strengthens autonomy of self-government and has been in effect since 1 January 2005.

The decentralization of public finance as a consequence of vast transfer of competences from state administration to municipalities and self-governing regions in 2002-2004 was an integral part of transformation of Slovak economy. ${ }^{57}$ "Altogether, in 2002 and 2003, 94 competences were transferred to regional government and 63 to self-government". ${ }^{88}$ Phase one of fiscal decentralization was subsequently carried out and within the first phase, the specific and temporary regime of funding transferred competences was applied in the form of the decentralization subsidy ${ }^{59}$ from the state budget. ${ }^{60}$

This way of financing also brought several problems. For example, the decentralization subsidy did not reflect a change in regime when transferring responsibilities from state administration to territorial self-government, e.g. it did not reflect payments to insurance systems of employees, property insurance. In addition to their responsibilities, Selfgovernments took over shortcomings caused by improper management of state properties: often-unsettled properties; missing documentation; auditor's reports, constructions in progress, excluding any financial compensation. Another problem was that the state transferred competences to all municipalities but did not transferred to them the necessary amount of finance. A considerable problem was that the state did not allow rational selfgovernment and effectively assets management because of the obligation to preserve the purpose of the transferred property. ${ }^{61}$

A change in finance was required as problems remained. From 1 January 2004, the purpose subsidy changed to a global subsidy divided in current expenditure and capital expenditure. The division of the subsidy is within the competence of higher territorial unit authorities. Responsibilities performed in the name of the state further remained funded by purpose subsidy. ${ }^{62}$ In 2005, Phase Two of fiscal decentralization started. Its goal was to strengthen financial autonomy of territorial self-government; to increase pressure on more

56 Kováčová (2010).

57 Kozovský, Žárska (2008).

58 Slavík (2011) 115.

59 I.e. purpose-driven subsidy from the state budget to ensure a specific responsibility.

${ }^{60}$ Kozovský (2005).

61 Nižňanský (2005).

62 Kováčová (2010). 
effective spending of own revenues and also on interconnection of scope and quality of services, provided by self-government with an impact on tax burden of population. ${ }^{63}$

In 2004, integrated offices of local state administration came to an end, with the abolishment of 79 district offices, as a result of transferring competences to municipalities and self-governing regions. To carry out the minimum remainder of state competences, the offices of specialized state administration, regional and circuit offices were reopened. The number of circuit office locations was set at 50, the original plan was 46 but once again the government parties pushed forward their "priorities" and their nominees. "The main reason of this step was "rationalization" of the network, however, if, apart from the seats of offices, we also count branches of circuit offices (64), their total highly exceeds the number of districts, 79". ${ }^{64}$

In the same year, the government discussed the intention to implement the municipal reform, i.e. gradual merging of municipalities in Slovakia (municipalization, amalgamation). ${ }^{65}$ They did not come to the resolution due to coalition disputes that resulted in the early elections in 2006. The municipal reform has since stagnated. Act of the National Council of the Slovak Republic No. 254/2007 Coll. abolished regional offices as of 1 October 2007 (general local state administration) with competences were transferred to circuit offices, with general competency. In 2009, the government adopted a concept of modernization of territorial self-government whose goal is to make transferred performance of state administration more effective; shift the process of informatization and introduce a monitoring system. Proposals for implementation of measures were postponed until the 2010 elections.

The new government comprised different political parties and their programme statement contains the following formulation: "The government of the SR will carry out a municipal reform that will motivate municipalities towards voluntary cooperation, merge administrative capacities and amalgamate municipalities. They will support common municipal offices that should create better conditions for contact of citizens with offices, rationalize and improve the activities of authorities of local self-government. The government of the SR will seek to strengthen the independence of control of territorial selfgovernment" ${ }^{66}$ The goals were not met because the government lasted only for a year and half. However, in public administration, the Ministry of Environment that was abolished by the former government was reopened and obligatory publication of contracts of state administration and self-government on the internet including several other anticorruption measures were taken. Cutting public administration costs and reducing the number of officials was on the agenda of the former as well as current government.

The program statement of the current government relies on the reform of public administration. 64 regional offices have been abolished since 1 January 2013 and Act No. 345/2012 Coll. on certain measures concerning self-government has been in effect. The act is fulfilling the objectives of the government's program statement for 2012-2016 and ESO Program, effective, reliable and open state administration. One of the first steps towards achieving these objectives is to develop a new structure of local authorities of

${ }^{63}$ Kováčová (2010).

${ }^{64}$ Slavík (2011) 111.

65 In Slovakia there are over 2,900 municipalities. There are studies that say that it is possible to achieve about 160-300 municipalities in Slovakia, which is a long-term process.

66 Government Office of the SR, 2010. 
state administration whose principles will be to simplify citizens' contact with state administration, transparency, effectiveness of public finance spending and efficient control.

The competences of regional school authorities, regional construction authorities and territorial military administration authorities were transferred to the existing circuit offices at the region seat within the competence of Ministry of Interior of the SR. The state property within the competence of the offices was transferred to the competence of the Ministry of Interior of the SR, identically, also personnel competence with respect to the staff. ${ }^{67}$ Competences of the abolished regional environmental authorities, regional land offices, regional forest offices, cadastral offices, regional offices for road transport and roads were transferred to the competent specialized body of a lower degree within the competence of the relevant central body of state administration e.g. regional environmental offices were transferred to circuit environment offices in the seats of regions within the competence of Ministry of Environment. ${ }^{68}$

Phase Two of the reform has been active since October 2013. From October 2013, district offices were established with seats in 72 districts, compensating the existing 50 circuit offices. 248 local bodies of state administration will be faded out of existence. During Phase Two of the reform, all circuit offices of environment, circuit offices for road transport and roads, circuit forest offices, circuit land offices and cadastral administration authorities will also cease with power transferred to the integrated local body of state administration with a new name district office. ${ }^{69}$

Citizens should have a single office where will be able to solve most scenarios. The largest cities Bratislava and Košice should have one district office, it means for each town one district office. In Bratislava, there had been 8 circuit offices up to the latest reforms, Košice citizens had 4 circuit offices. Along with district offices, client centers will emerge where citizens will be able to submit their applications. As of January 201643 of them are in operation, the others gradually opened in a course of the next years, totalling 79.

Client centres should be accessible by anyone within $50 \mathrm{~km}$ distance from their permanent residence or maximum by one hour of travelling by public transport. ${ }^{70}$ The competences of newly opened district offices include matters in relation with transfer of property at the cadastre of real estate property; environmental care; issuance of trade licenses; spatial planning; construction and housing policy; school administration matters; abolition or establishment of kindergartens; specialized primary or elementary schools; vocational colleges; bilingual schools; hunting matters; management of forests; land adjustments and state defense. ${ }^{71}$

It is not yet clear how will the entire public administration reform will end. The opinions about detailed elements and the concept are absolutely different between politicians and expert communities. For every mention of integration, public finance saving and public administration closer to citizens, the opposition and some critics talk about concentration of power by Ministry of Interior of SR, the return to centralization and generally, about strengthening of state functions. It will be possible to analyze government action after adoption of specific legislation and implementation of the reform in practice.

${ }^{67}$ MV SR (2013).

${ }^{68}$ MV SR (2013).

69 SITA (2013).

70 Vavrová (2013).

71 Vavrová, Krbatová (2013). 


\section{CONCLUSION}

Despite the reforms being required, there is a lack of political willingness to encourage the municipal reform (municipalization) and thus there will be no final decentralization. The issue of informatization of public administration and e-government remains marginal. The territorial and administrative division of Slovakia, despite being continuously criticized and has not changed since 1996. Based on the division, changes in public administration and in self-government have been implemented. The functioning of 8 regions and 8 selfgoverning regions regardless natural regions, traditions and history has had a negative influence on citizens to identify with the units.

On the other side, 12 or 16 natural regions could be an end to any rationalization and higher ineffectiveness; spending of public finance on new offices, presidents, members of parliament or their possible "poor" management. The greatest challenge of any change is the need of legislation to avoid overgrowing public apparatus, paid officials, budget and contributory organizations, general bureaucracy or politicking at the expense of development of regions, municipalities and state. What remains embarrassing is that, despite the establishment of regional self-government and the transfer of over 400 competences to selfgovernment authorities, there is no approach to a revision of some competences because self-governments are not able to fund it and they do not have human or other resources. There is a lack of coordination and unification, meaning that centralization is required in certain cases. However, in most cases the transfer of competences was the right choice.

Opinion disunity and deficit of a common strategic vision for building public administration remain common in Slovak society and politics. An example is not only abolition and renewal of the Ministry of Environment of the SR within one year but also postponing of abolition of the National Property Fund; the failure to solve the issue of overemployment in the public sector and low productivity of labour. The greatest problem is that only in the last 20 years some permanent changes have been made in general and specialized state administration. The establishment of specialized circuit offices, their termination and creation of general district offices, establishment and termination of regional offices, administrative transfers and in some cases only changes in the names of offices with no deeper thoughts of the competent ones, abolition of regional offices and only renaming to circuit offices with general competence, renaming of circuit offices to district offices!

There is often a question if such changes save any material, human and other resources and whether they really contribute to the improvement of the functioning of the segment. The question of deconcentration in public administration, decentralization or centralization in public administration is almost a Hamletian question. A common answer has to be found. Offices and their elected or appointed representatives are here to serve citizens and citizens should not feel that they serve offices or that they are bullied by them. It is an obligation of experts and politicians to make the system of public administration functional and quality in every respect. This cannot be achieved by changing the position and structure of state administration authorities in principle three times in the period between 1996-2013. Simply said, the moral aspect of tolerance considerably absents in the reform process in Slovakia. The position of power and absolute intolerance against political opponents or disapproving attitude from other spheres of community threw Slovakian society into a vicious circle, where long strategic visions exceeding one or two election periods do not have a chance to be pushed forward because of limited vision and inability to make an agreement for the good of all i.e. in the public interest for public welfare, which is a basic attribute of public governance. 
Franz Grillparzer expressed an idea that "no shortcomings of other people cause us to be more intolerant than those which are caricatures of our own". By repeating the same mistakes in a short sequence people only prove how incorrigible and obstinate they are. Not accepting and embracing a quality idea of opponents only because it is not their idea, is a sign of low manners and immaturity. The political culture of post-communist societies, including the Slovak Republic, is limping along. Public institutions should be carriers of such values in democratic society, but unless people who work for them implement such values in them, Slovak society cannot expect that institutions will cultivate following generations, institutions will only deepen decadence and bad habits of previous regimes and fashion waves in politics.

\section{LITERATURE}

Beblavý, M., 'Management of Civil Service Reform in Central Europe' in G Peteri (ed), Mastering Decentralization and Public Administration Reforms in Central and Eastern Europe (Open Society Institute 2002) 55-72.

Belajová, A., Balázová, E., Ekonomika a manažment územnej samosprávy (SPU 2004).

Búšik, J., 'Reformné procesy v štátnej správe' in E Žárska and M Šebová (eds), Decentralizácia verejnej správy Slovenskej republiky - otvorené otázky (EUBA 2005) 7-18.

Cabada, L., 'Formální decentralizace a nefunkční víceúrovňová správa jako překážka procesu evropeizace - př́iklad Bosny a Hercegoviny’ in B Dančák, B. and V Hloušek (eds), Viceúrovňové vládnutí v Evropě: zkušenosti, problémy a výzvy (MU 2007) 91-106.

Chapman, R. A. and others, Etika ve veřejné službě pro nové tisiciletí (Slon 2003).

Cirner, M., 'A Comparison of Public Administration in Ukraine, Poland and Slovakia' in I Dudinská and I Kozárová (eds), Public Administration Reform in Ukraine: Lessons Learned from Slovakia and Poland (Vydavatel'stvo Prešovskej univerzity 2014) 139-153.

Cirner, M., 'Reforma štátnej správy ESO - návrat k centralizácii verejnej správy na Slovensku?' in V Bobáková and others (eds), Zbornik príspevkov z medzinárodnej vedeckej konferencie „,Teória a prax verejnej správy" (FVS UPJŠ 2013) 61-71.

Cirner, M., Polačková, A., 'Zákon o meste Košice - permanentná výzva pre politikov i samosprávu' in D Ondrová (ed), Aktuálne problémy a výzvy verejnej správy (FVS UPJŠ 2012) 142-148.

Drechsler, W., 'Public Administration in Times of Crisis' in R Kattel and W Mikulowski and BG Peters (eds) Public Administration in Times of Crisis (NISPAcee 2011) 15-25.

Gecíková, I., Papcunová, V., Metódy a techniky regionálnej analýzy (Sprint dva 2011).

Hamalová, M., Teória, riadenie a organizácia verejnej správy. 1. čast': Teória verejnej správy. (Merkury, spol. s r.o. 2007)

Hamalová, M., Papánková, S., 'K aktuálnym problémom komunálnej reformy v SR' in E Žárska and M Šebová (eds), Decentralizácia verejnej správy Slovenskej republiky - otvorené otázky (EUBA 2005).

Hambálek, A., '10 rokov regionálnej autority v podmienkach Slovenskej republiky' in T Mikuš (ed.), Otvorená samospráva I. Zborník z konferencie k 10. výročiu vzniku TSK (Úrad TTSK 2011) 111120.

Hendrych, D., 'Úvod do správní vědy' in M Novák and others (eds), Úvod do studia politiky (Slon 2011) 377-392.

Hloušek, V., Kopeček, L., 'Konsolidace demokracie a hybridní režimy - slovenský a chorvatský př́ipad' (2003) 5 Středoevropské politické studie 12-25.

Kačala, J., Pisárčiková, M., Považaj, M., Krátky slovník slovenského jazyka (Veda 2003) Available at: $<$ slovnik.juls.savba.sk/?w=reforma=B04a $>$ accessed 29 May 2015.

Klimovský, D., Základy verejnej správy (FVS UPJŠ 2008).

Kolarska-Bobiňska, L., The Second Wave of Polish Reforms (Instytut Spraw Publicznych 2000).

Kováčová, E., Verejná správa na Slovensku. Úlohy a postavenie územnej samosprávy (FPVaMV UMB 2010). 
Kozovský, D., 'Otvorené otázky fiškálnej decentralizácie v SR' in E Žárska and M Šebová (eds), Decentralizácia verejnej správy Slovenskej republiky - otvorené otázky (EUBA 2005) 96-102.

Králik, J., Samospráva a jej miesto v politickom systéme (FPVaMV UMB 2007).

Light, C. P., 'The Tides of Reform Revisited: Patterns in Making Government Work' in R Stillman J. (ed). Public Administration. Concepts and Cases (Wadsworth 2010) 372-390.

Machyniak, J., 'Aktuálne problémy verejnej správy - výsledok zápasu o moc' in D Ondrová (ed), Aktuálne problémy a výzvy verejnej správy (FVS UPJŠ 2012) 122-130.

Matei, A., Popa, F., 'Impact of Decentralisation on the Corruption Phenomenon' in J Nemec and BG Peters (eds), State and Administration in a Changing World (NISPAcee 2010) 259-269.

Neubauerová, E., Finančné aspekty decentralizácie verejnej správy (Ekonóm 2003).

Nižňanský, V., Decentralizácia na Slovensku. Bilancia nekonečného príbehu 1995-2005 (Úrad vlády SR 2005).

Nižňanský, V., 'Spoločenský, historický a európsky kontext reformy verejnej správy na Slovensku' in G Mesežnikov and V Nižňanský (eds), Reforma verejnej správy na Slovensku 1998-2002. Súvislosti, aktéri, vol'by (Inštitút pre verejné otázky 2002).

Nižňanský, V., 'Spor o charakter štátu a decentralizácia' in M Bútora and M Kollár and G Mesežnikov and Z Bútorová (eds), Kde sme? Mentálne mapy Slovenska (Kalligram 2010) 170-180.

Pilát, J., 'Inštitucionálny aspekt reformy verejnej správy' in G Mesežnikov and V Nižňanský (eds), Reforma verejnej správy na Slovensku 1998-2002. Súvislosti, aktéri, vol'by (Inštitút pre verejné otázky 2002).

Pomahač, R., Vidláková, O., Verejná správa (C. H. Beck 2002).

Pomahač, R., Základy teorie veřejné správy (Aleš Čeněk 2011).

Slavík, V., Geografia verejnej správy (UK 2011).

Sotolár, J., Zákon o obecnom zriadení (Sotac 2003).

Vavrová, V., Krbatová, L., 'Vel'ká zmena na úradoch od októbra', Pravda (2013). Available at: $<$ http://spravy.pravda.sk/domace/clanok/284299-kalinak-reforma-esousetri-este-viac $>$ accessed 8 September 2015.

Vavrová, V., 'Premena úradov bude t’ažkou skúškou', Pravda (2013). Available at: <http://spravy. pravda.sk/domace/clanok/284468-premena-uradov-bude-tazkou-skuskou/>. accessed 8 September 2015.

Vykoupilová, H. 'Více úrovňové vládnutí v Evropě: koncepce, modely, typy' in B Dančák and V Hloušek (eds), Viceúrovňové vládnutí v Evropě: zkušenosti, problémy a výzvy (MU 2007) $13-27$.

Waisová, Š., ‘„Jedna velikost nesedí všem“: K čemu vede aplikace neoliberálního konceptu vládnutí ve slabých státech?' in B Dančák and V Hloušek (eds), Viceúrovňové vládnutí v Evropě: zkušenosti, problémy a výzvy (MU 2007) 107-120.

Žárska, E., Černénko, T., Kozovský, D., Verejná správa I. (EKONÓM 2010).

Žárska, E., Kozovský, D., Teoretické a praktické aspekty fiškálnej decentralizácie (Vydavatel'stvo EKONÓM 2008). 